UDC 371.11:373.2

DOI: $10.52534 / \mathrm{msu}-$ pp.7(4).2021.58-65

Iryna Yu. Mosiakova*

Bohdan Khmelnytsky Melitopol State Pedagogical University

72300, 20 Hetmanska Str., Melitopol, Ukraine

\title{
Theoretical Foundations for the Management of Multidisciplinary Institution of Out-of-School Education in the Conditions of Autonomy
}

\section{Article's History: \\ Received: 05.10.2021 \\ Revised: 06.11.2021 \\ Accepted: 10.12 .2021}

\section{Suggested Citation:}

Mosiakova, I.Yu. (2021). Theoretical foundations for the management of multidisciplinary institution of out-of-school education in the conditions of autonomy. Scientific Bulletin of Mukachevo State University. Series "Pedagogy and Psychology", 7(4), 58-65

${ }^{*}$ Corresponding author

\begin{abstract}
A topical issue in the system of Ukrainian and foreign education is the rethinking of the methodology for the management of out-of-school educational institutions. The purpose of the study is to reveal the content of scientific approaches and scientific disciplines for the development of educational management in multidisciplinary out-of-school education institutions. The study uses systemic, procedural and synergistic methodological approaches using methods of analysis and synthesis, systematisation, comparison, analogy. The study presents the results of the analysis of the research papers on theoretical approaches to management, reveals the essence of the concepts related to educational management as a new area in science and practice. The range of sciences that would contribute to the development of a new management paradigm for multidisciplinary out-of-school education institutions (philosophy of education, social philosophy, social psychology, sociology, etc.) is outlined, emphasis is placed on the principle of institution autonomy. The study reveals the regularities of the theoretical model of management of a multidisciplinary institution of out-of-school education (mapping the individual trajectory of professional development of teachers, which contributes to a deeper understanding of their needs and, consequently, potentially improving the quality of educational services; and, accordingly, the adjustment of management actions; management of phased processes of development and implementation of author's educational programmes that should guarantee the quality of educational services, assess the feasibility of their implementation in accordance with the interests of applicants, analyse after their experimental implementation). The practical significance of the study is conditioned by the possibility of using materials in higher education institutions within the educational programmes "Educational, pedagogical sciences". Materials can be useful for improving the skills of heads of multidisciplinary institutions of out-of-school education for adults (both formal and non-formal education), in postgraduate education institutions to improve the professional competence of administrative staff of multidisciplinary out-of-school education
\end{abstract}

Keywords: reform of the out-of-school education system, systemic, procedural and synergetic approach, adult education, educational management

\section{INTRODUCTION}

Trends in the development of management in education, which are inherent in modern society, require new approaches to ensure the development of a modernised paradigm of educational management. The head of the educational institution, teachers, and students are at the centre of reforms, and that is why new knowledge is needed in this area, updating best management practices, analysis of rational areas of work with teaching staff, creating new models, introducing new educational programmes, etc. The problem of governance in education is conditioned by ideological and socio-economic changes in society, the desire to build democratic foundations of coexistence.

Creating a theoretical basis for effective educational management is not possible without the use of the best 
developments and ideas that are accumulated today in foreign and Ukrainian literature. The key issue of educational management remains the consolidation of business and interpersonal relationships between educational entities (F. Díez, A. Villa, A. López, I. Iraurgi [1]), improvement of the quality of educational services for applicants (M. Matsuo, T. Tsukube [2]), and in the system of out-of-school education (G. Pustovit, V. Verbytskyi, R. Pavelkiv [3]) - management in the line of building various profiles (artistic and aesthetic, scientific technical, ecological and naturalistic, tourist and local lore, physical culture and sports, research and experimental, humanities).

The demands of the time, including digitalisation and informatisation of education, the need to organise educational management based on democratic principles of governance, the transition to a new paradigm of education, the introduction of quality education systems, etc., encourage representatives of multidisciplinary outreach institutions levels - both personal and institutional. For the educational management of multidisciplinary out-of-school education institutions the scientific basis is the work of Ukrainian and foreign researchers on updating the content of educational management (V. Antonov [4], N. Nychkalo, A. Molchanova, and N. Klokar, etc. [5], I. Zastrozhnikova [6]). In particular, I. Zastrozhnikova, drawing attention to the development of education, reveals the regularity of the dependence of human development on the state as an institution that has real opportunities for knowledge management in Ukraine. The researcher emphasises the importance of the main resource for state educational policy - regional educational policy, which implements the processes of human development $[6$, p. 147-148].

The issues of democratisation of relations in the system "student/parent/public self-government bodies - director / head - pedagogical worker - students" are revealed by such scholars as D. Challenger [7], R. Laursen [8] et al. In particular, R. Laursen's study emphasises the disclosure of the issue of professional leadership in educational institutions in Denmark, and points to the emergence of a tendency to "forget the role of educational institutions as key democratic institutions" [8]. The scientist rightly notes that it is in educational institutions that such management methods should be spread, which would generally lead teachers to instrumental and harmonised education of students. The researcher argues for the need for democratic governance and emphasises that "... principals are accountable to municipalities to ensure such an approach in the educational institution" [8, p. 361-362], and therefore they are responsible for what happens inside the institution. Thus, it can be considered natural that the development of educational management depends on the management decisions made by the representatives of the regional educational policy, to which the directors of educational institutions are accountable.

Recent studies also emphasise the saturation of educational management with quality information data (A. Kolesnikov, L. Bilovus and O. Oliynychuk [9]), the importance of scientific management of pedagogical systems in crisis conditions (G. Alonso-Yanez, S. Friesen, A. Preciado-Babb and B. Brown [10], R. Khanal [11] et al.). Thus, it is possible to highlight another pattern - the dependence of regional educational policy on the scientific training of heads of educational institutions operating in different regions, their digital competence, and directly on the infrastructure available in the region. In particular, R. Khanal's study highlighted the crisis in the management of pedagogical systems in which the heads of educational institutions found themselves during the quarantine caused by COVID-19: “... developed countries have an advantage because they already have a well-established infrastructure to support remote access to e-learning" [11]. The researcher highlights the importance of the procedural approach to management in the crisis period conditioned by the temporary economic and social requirements. At the same time, the researcher emphasises the unprecedented situation for many educators and focuses on tools that could be used to facilitate management in education.

The purpose of the study is to reveal the content of scientific approaches and scientific disciplines for the development of educational management in multidisciplinary out-of-school education institutions.

\section{MATERIALS AND METHODS}

The study draws conclusions based on theoretical analysis of legislative documents, dissertation research, materials of papers and monographs of both foreign and Ukrainian researchers. The study results are summarised based on qualitative data (theoretical design that provides an opportunity to highlight the main approaches and theories to the management of multidisciplinary autonomous out-ofschool education). The study results could be summarised to describe the recommendations for the development of educational management, but such generalisation is not the purpose of the study, as this paper analyses broad social phenomena that are transforming and acquiring new characteristics in accordance with the development of a culture of autonomy of a democratic society, causing changes in the education system.

The study used the following methods:

- analysis to determine trends in the development of out-of-school education during the establishment of a democratic society, where one of the principles of cooperation in educational institutions at the institutional and interpersonal level is the spread of autonomy;

- analysis to identify meanings in research papers, real practice, revealing issues of educational management in the process of implementing reforms by out-of-school subjects, their adaptation to the management structure of multidisciplinary out-of-school educational institutions in the gradual development of autonomy;

- description of the positions of researchers on the use of scientific approaches in the management of social systems and consideration of their relationship in the real space of out-of-school (reflecting the features of scientific 
approaches taking into account existing changes in multidisciplinary out-of-school education);

- introduction of the concept of "management of a multidisciplinary institution of out-of-school education", a description of its features;

- synthesis of multidisciplinary knowledge to create a theoretical construction of new knowledge about the management of multidisciplinary out-of-school education institutions in the conditions of autonomy;

- comparison (information on educational management, modern management paradigm and its comparison with the previous paradigm);

- generalisation to formulate ideas for theoretical understanding of real practices of management of multidisciplinary institutions of out-of-school education in the conditions of autonomy.

The study used the method of analysis in the process of elaboration: 1) Strategy for the development of out-ofschool education, in which one of the key vectors is the management vector [12]; 2) Law of Ukraine "On Education" to identify a fragment of changes in social reality - the right of autonomy to self-government [13].

The research has an interdisciplinary nature, which uses not only knowledge of pedagogy, nonscholastic pedagogy, but also such disciplines as "Philosophy of Education", "Social Philosophy", "Sociology", "Sociology of Education". Such interdisciplinary emphases help to fill gaps in the structure of new scientific knowledge about educational management in multidisciplinary out-of-school education institutions and create a theoretical construct to ensure the organisation of basic concepts and categories as accepted for extracurricular activities. This is relevant for the further design of disciplinary knowledge into a single system, which has laws, substantive characteristics, general and specific principles, taking into account the personal and professional traits of the director and leaders of educational reforms as drivers of quality out-of-school education.

Thus, the analysis of the theoretical foundations focuses on the study of how the management system of multidisciplinary institutions of out-of-school education is possible to influence the social reality.

\section{RESULTS AND DISCUSSION}

\section{Characteristics of the content of scientific approaches to the management of multidisciplinary out-of-school education institutions in the conditions of autonomy}

The intensity of transformations in the educational sphere, in particular, with the introduction of the key principle the autonomy of educational institutions, puts forward new requirements for the management of multidisciplinary outof-school educational institutions. It not only includes renewing the relationship between out-of-school activities, but also modernising the entire content of educational management, which requires theoretical generalisation and further understanding to predict the process of providing educational services.
In the Strategy for the development of out-of-school education, one of the vectors of development is management, which, in turn, is characterised by three strategic goals, namely: "1) staffing, creating appropriate conditions for professional development and work; 2) development of out-of-school education management; 3) expansion of cooperation" $[12$, p. 64]. In other words, the need for theoretical understanding of the management vector of outof-school education is largely determined by the level of training of management staff, their willingness to manage in the autonomous conditions.

The more complex and larger the structure of a multidisciplinary out-of-school education institution, the larger the tasks facing the head, and hence the issues of their practical implementation, given the rapid deployment of educational and cultural space. I. Kushnir gives the right opinion in this regard: "In recent years, educational institutions of Ukraine have come a long way from monotony, unitarity to variability, diversity. The idea of subordinating the educational process to the task of educating the individual is gaining momentum, many innovative educational institutions have appeared, the content of education is being updated and improved, forms and methods of teaching and educational work are being modified, educational space is based on democratic principles" [14, p. 28].

In addition, the development of out-of-school pedagogy, leisure pedagogy as separate areas in the field of pedagogy is one of the reasons for increasing attention to the management of teachers in out-of-school institutions, which is extremely limited to date in scientific and methodological sources. In addition, the social and managerial concept of leisure activity, which was presented as a product of command and administrative activity, is being replaced today by another that is devoid of rigid management, because the idea of democratisation of management and, in particular, culture of out-of-school autonomy, without violating individual spiritual features, is a valuable basis for working with teachers and applicants for educational services. The dominance of autonomy at all levels (personal, interpersonal, institutional, and interinstitutional) is the basis for the development of educational management, organisation of out-of-school education, organisation of the head in accordance with the basic functions of management (planning, organisation, motivation, control, etc.), social protection - educational process. The autonomy is consolidated in the Law of Ukraine "On Education" and is interpreted as follows: "autonomy is the right of the subject of educational activity to self-government, which consists in its independence and responsibility in making decisions about academic (educational), organisational, financial, personnel, and other issues of activities carried out in the manner and within the limits prescribed by law" [13]. Thus, the issue of observance of this right is connected not only with the existence of legal requirements, but also with the needs of the individual to manifest themself in the behaviour of independence and, accordingly, responsibility for decision-making. The study suggests that in the case of the use 
of such rights by the subjects of out-of-school education, it becomes possible to realise their own need for creativity, which best develops human potential.

Modern researchers need to enrich both out-of-school and leisure pedagogy with new concepts, ideas, and methodological approaches to management. They are aware of the need to close the gaps in this area. The fundamental point for solving the issue of managing a multidisciplinary institution of out-of-school education is the establishment of an appropriate terminology and the construction of a holistic scientific view of the culture of autonomy in educational management, which is possible considering philosophy (social), psychology (social), sociology and educational methodology in an organic combination will objectively reflect the diversity of the phenomenon under consideration and its individual elements.

The unification of the scientific concept of "autonomy in the management of out-of-school institutions" took into account that this concept is formed not only through theoretical considerations but also through professional understanding of the best democratic management practices, so the defining feature of this concept is its interdisciplinarity. The study of the management of multidisciplinary out-of-school education institutions also took into account the existence of different profiles that affect the activities of out-of-school education entities in different ways. In reality, the issue of educational management of out-of-school institutions is determined by the positions of improving the organisation of pedagogical work, efficiency of educational process, making managerial decisions based on values, minimising conflicts between representatives of the institution and so on. All this would help improve the quality of human resources, improve the vertical and horizontal management, improve cooperation and more.

One of the important approaches to the management of a multidisciplinary institution of out-of-school education is systemic. According to researchers, this approach helps to look at management as a dynamic and at the same time static phenomenon, helps to assess the institution from the standpoint of its development, will allow consideration of its internal organisation. Thus, D. Dzvinchuk, V. Malimon, V. Petrenko point out: "A systematic approach to management emerged in the 1960s, based on the so-called theory of general systems, according to which management is considered not as a series of functionally conditioned elements arising from each other, not as a "one-dimensional" phenomenon, but as a multifaceted set of management actions to ensure interconnection its external environment" [15, p. 21-22]. The authors point out three differences between the procedural approach and the systems approach to management. Thus, the first difference is "the recognition of the organisation as a complex, multidimensional system with appropriate management requirements, which should take into account the influence and interaction of many external and internal factors that have a direct and indirect impact on the organisation" $[15$, p. 22]. The second difference is the consideration of the synergetic effect, because "the whole is always qualitatively different from the simple sum of its constituent parts" $[15$, p. 22$]$. The third difference is the consideration of changes in each element of management with the assessment of necessary and appropriate changes in all other elements, and, ultimately, the entire organisation, which requires extremely comprehensive solutions to any problems of the organisation: large and small, simple and complex, current and future" $[15$, p. 22]. That is why a systematic approach to the management of a multidisciplinary institution of out-of-school education characterises the institution as a complex and multidimensional system in which it is possible to explore its optimal functioning taking into account external and internal factors that affect the dynamics of its development and the very image of both the head and the teaching staff and graduates.

However, the director of a multidisciplinary institution of out-of-school education cannot reject the procedural scientific approach to management, because it is the procedural approach that embraces the reality in the activities of teachers and students of out-of-school education. These are relationships, peculiarities of behaviour, and the practice of becoming a person as a free person - experiential, active, which is sometimes more complex than the idealised construct. It is the procedural approach that helps maintain the balance of the constructed management system in motion, the dynamics of each day, week, month, etc. At the same time, it is important for the movement of educational management to work not only to acquire cognitive skills, but also skills for later life, i.e., those skills that are considered key to human life in the $21^{\text {st }}$ century. To this end, the activities of administrative staff should be directed to the development of management education of both the younger generation and adult members of the management elite in combination with coaching, tutoring, psychological support, and more. In this context, the concept of "management of a multidisciplinary institution of out-of-school education" involves the process of formalising existing information about the object and subject of research, requires generalisation of new ideas, best practices that will be system-forming factors.

It was taken into account that the educational management of a multidisciplinary out-of-school educational institution determines not only the issues of planning and control of educational services, but also the development of new management models, which should be based on the principles of legality goals, etc. There are three patterns that underlie this model. Thus, the first of them is: improving the quality of educational services depends on mapping the individual trajectory of professional development of teachers. Notably, pedagogical workers who work with out-of-school students every day have certain needs. A deep understanding of these needs by the director and administration of the institution should be the basis for developing a plan-map for the professional development of each teacher. Secondly, the development of educational management of the institution largely depends on the information provided by stakeholders as person interested in the quality of out-of-school education. Accordingly, such information is influential for 
the adjustment procedures of the principal and administrative staff of a multidisciplinary out-of-school educational institution. Third, the interests of out-of-school education seekers should be the focus of educators who develop author's educational programmes. The quality of educational services can be guaranteed if the authors implement their thoughts through the understanding of real practice, and the tested programmes are introduced in stages, after a series of experimental work with students of out-of-school education.

A wide range of available data helps to organise a synergetic approach, in particular, in the educational environment (S. Lovely, A. Baffum, R. Barth [16]), which focuses on the processes of self-organisation, self-improvement in the interaction of different generations, studying internal and external relationships, connections, processes of integration in amateur performance, self-management. In this sense, it is also appropriate to refer to the work of V. Budanov "Methodology of synergetics in post-classical science and education" where, given a synergistic understanding of the position of educational institution management: which, in fact, should become a reflective control loop, in addition to the administrative vertical. They must perform holistic management: from the creation of an innovative environment and exchange of experience, to the creation of recommendation methods, regulations, and inspections" [17, p. 210]. Thus, through management practices based on self-government, self-organisation, taking into account the ideas and thoughts of different generations, etc., it becomes possible to expand the educational space of out-of-school education in autonomy. This would allow building a variety of areas that, in combination, will help to develop educational management at the present stage.

That is why the methodological foundations in the management of a multidisciplinary institution of out-ofschool education are: 1) knowledge of educational management, taking into account the real processes taking place in the field of out-of-school education; 2) awareness of pedagogical workers of the right to autonomy, expression of pedagogical creativity, the need to develop human resources, taking into account the goals and objectives, laws, principles, forms, methods of out-of-school pedagogy and leisure pedagogy; 3 ) ensuring the adaptability of management activities in accordance with the changes to create and maintain the success of the institution.

With this in mind, the management of a multidisciplinary institution of out-of-school education is designed to ensure systematic activities that will consider the influence of external and internal factors, comprehensive solutions to problems arising in the realities of human activities, synergies, etc. Thus, knowledge of the process of managing a multidisciplinary institution of out-of-school education involves systematisation of scientific approaches, highlighting their benefits, respectively, real and ideal, where non-experiential concepts are human freedom, freedom of teaching staff, autonomy of the institution (Fig. 1).
System approach

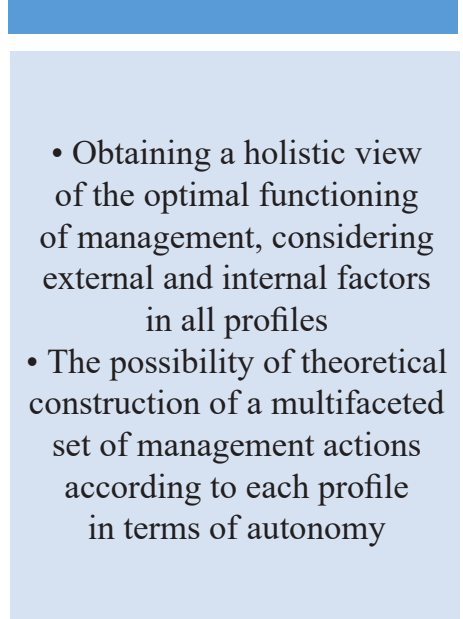

Procedural approach

- Maintaining the balance of the constructed control system in motion

- Consideration of regularities in new conditions, correction of administrative actions - The possibility of real adaptation of best management practices in the institution - Consideration of the gradual development of the culture of autonomy of the institution
Synergetic approach

- Reflection of the received data for creation of an innovative environment

- Generalisation of experience of self-management, self-organisation, self-improvement

- Expanding the educational space for innovations in the field of extracurricular activities

Figure 1. Scientific approaches to the management of multidisciplinary out-of-school education institutions and their advantages

\section{The importance of humanities for the development of educational management of multidisciplinary out-of- school education institutions}

Knowledge of the management process is conditioned upon the desire of the head to achieve self-efficacy, a new level of professional competence, which arises from the emergence of a new view of the content of extracurricular education.
However, at the same time, managers are concerned about the following questions: How to help increase the effectiveness of management technologies in the educational context of extracurricular activities? How to cope with the pressure of socio-economic and organisational conditions?

Fundamental to the management of a multidisciplinary institution of out-of-school education are the ideas that are developing in the direction of the philosophy of 
education. Cognitive categories of philosophy of education provide an opportunity to characterise the content of management and, accordingly, to express its essence through such positions as structure and its elements, individual and collective, considering the autonomy of the organisation of extracurricular education. For management, the philosophy of education plays a constructive role, because it distinguishes the gap between the ideas of management as the absolutisation of forms of norm control and the ideas of organising the work of the institution with autonomy as an active beginning of society. It is the philosophy of education that helps educational management to see the extreme points that are consolidated in the management process, to understand the existing barriers that hinder development. That is, the management of a multidisciplinary institution of extracurricular education has a unique philosophical basis that enriches the understanding of educational management, develops the terminology within the categories directly related to research, namely: "management", "leadership", "monitoring", "control", which are saturated with new content, because they cover the new reality.

In addition, for the compilation of research methodology should take into account theories that develop within the framework of social philosophy. In this regard, the study considers the fundamental work of Yu. Bekh's "Philosophical Mode of General Management Theory", which emphasises that today is an active search for a modern management paradigm: changes and processes of globalisation, with the spiritual revival of society and the individual, with power and political stabilisation, with the problems of achieving economic efficiency and social justice" [18, p. 11]. One of the important sciences related to the management of a multidisciplinary institution of out-of-school education is psychology, in particular, social psychology. The dialectic of the relationship between social philosophy and social psychology is considered by P. Gnatenko, S. Shevtsov [19]. The researchers point out the main differences: "if social psychology is aimed at classes of individual and supra-individual phenomena, social philosophy - on the universal principles of civilisational existence and development of society as a whole system through the prism of man and the value of humanistic priorities" [19, p. 87]. In the framework of scientific research, with the help of ideas engraved in social philosophy, for the management of multidisciplinary extracurricular institutions it is possible to consider the existence of the institution in society to implement humanistic values, discuss and implement desirable forms of human development. In leisure time, while within the framework of social psychology, the development of individuality, establishing joint interaction between individuals, patterns of individual and group behaviour, the principle of social influence of the reference group on the individual, the concept of "leadership", "responsibility", "comfort", etc. That is why social philosophy and social psychology is one of the basic foundations in the management of education, and, in particular, in the management of multidisciplinary institutions of extracurricular education.
To acquire systematic knowledge in management, it is necessary to apply the laws and patterns studied by sociology. Given that the management of a multidisciplinary institution of out-of-school education should be aimed at maintaining stability, improving efficiency, achieving sustainable development, it is within sociological knowledge that various factors influencing the decision-making process can be found, and problems related to levels, forms, and methods of management. The study suggests that it would be a big mistake to abandon the knowledge provided by sociology, because it works for the progressive development of society in general and the education sector in particular. The following issues are considered in the sociology of education management: the system of social action and social interaction, social relations between institutions and social communities, and, importantly for research, - extracurricular social communities. At the same time, educational management does not yet have certain standards and is just beginning to develop. In this regard, it is appropriate to define the concept of educational management, which is given in the book "Sociology of Education": "Educational management is considered as a branch of management that regulates the transformation of the content of educational activities; it covers the content, forms of implementation of principles, methods, approaches, technology, functions and techniques of managing the interaction of educational processes" [20, p. 260]. That is, agreeing with this view, the study takes into account that the management system appears as part of the management of social reality and is a dynamic phenomenon. The role of the head and pedagogical workers, their positions in the educational sphere can suffer from changes, because every day all subjects of out-of-school education gain new experience, acquire new knowledge, get acquainted with existing managerial and pedagogical practices.

\section{CONCLUSIONS}

Considering various ideas in the field of education management, there is an opportunity to reveal the importance of scientific approaches (systemic, procedural, synergetic) and scientific disciplines (philosophy of education, social philosophy, social psychology, sociology, etc.) to reflect the boundaries of educational management of multidisciplinary extracurricular institutions. It was found that skilful use of knowledge about scientific approaches, awareness of their advantages, characterisation of the importance of scientific disciplines for educational management will help the management elite to see resources and, accordingly, justify new ideas for building management models in the context of autonomy - as a human right in a democratic society. The need to improve the knowledge potential for directors/ future areas of multidisciplinary out-of-school education institutions, to develop their ability to search for management decisions based on interdisciplinarity, which plays an important role in their orientation in a complex world of knowledge is constantly saturated with new information. Thus, it is confirmed that the disclosure of methodological 
approaches in the management of multidisciplinary out-ofschool education institutions is appropriate for finding new, effective management solutions on the one hand, and on the other - the emergence of new issues for further research. For further research it is important to consider the relationship between the adoption and implementation of "smart" management decisions for multidisciplinary extracurricular institutions, substantiation of categories related to the culture of autonomy of extracurricular institutions, harmonisation in the development of extracurricular education, which would eventually contribute to new ideas, introduction of effective management practices, establishment of a new paradigm of educational management, etc. The issues of developing a scale for measuring the effectiveness of pedagogical activities in out-of-school institutions, a scale of satisfaction of applicants for out-of-school education institutions with services provided, quality characteristics of business and interpersonal communication in out-of-school education institutions, etc., remain open.

\section{REFERENCES}

[1] Díez, F., Villa, A., López, A.L., \& Iraurgi, I. (2020). Impact of quality management systems in the performance of educational centers: Educational policies and management processes. Heliyon, 6(4), article number e03824.

[2] Matsuo, M., \& Tsukube, T. (2020). A review on cognitive apprenticeship in educational research: Application for management education. The International Journal of Management Education, 18(3), article number 100417.

[3] Pustovit, H.P., Verbytskyi, V.V., Pavelkiv, R.V., Petrenko, O.B., Cherniy, A.L., Balika, L.M., Herevych, O.V., Drahomeretska, O.A., Zavalievskyi, Yu.I., Klymchuk, V.V., Lytovchenko, O.V., Machuskyi, V.V., Pervushevska, I.O., Sukhomlynska, O.V., Sushchenko, T.I., \& Tykhenko, L.V. (Eds.). (2017). Encyclopedia of extracurricular education. Rivne: Zen O.

[4] Antonov, V.M. (2018). Innovative acmeological pedagogy: Cyber-acmeological aspect of education quality management. Odesa: Kupriienko S.V.

[5] Kyrychenko, M.O., \& Serheieva, L.M. (Eds.). (2018). Open education: Innovative technologies and management. Kyiv: Institute of Gifted Child of NAES of Ukraine.

[6] Zastrozhnikova, I.V. (2020). State management of education at the regional level. Theory and Practice of Public Administration, 3(70), 147-153.

[7] Challenger, D.F. (2021). Why civic education is key to protecting democracy. Retrieved from https://nebhe.org/journal/ why-civic-education-is-key-to-protecting-democracy/.

[8] Laursen, R. (2020). Does the combination of professional leadership and learning management systems signal the end of democratic schooling? Research in Educational Administration \& Leadership, 5(2), 342-374.

[9] Kolesnikov, A., Bilovus, L., \& Oliynychuk, O. (2021). Information management: Certain practical aspects in education. Investytsiyi: Praktyka ta Dosvid, 15, 25-30.

[10] Alonso-Yanez, G., Friesen, S., Preciado-Babb, A., \& Brown, B. (2021). Emergence in school systems: Lessons from complexity and pedagogical leadership. Canadian Journal of Educational Administration and Policy, 196, 65-82.

[11] Khanal, R. (2021). Crisis pedagogy: Student perceptions of pedagogical transition amidst the COVID-19. Pedagogical Research, 6(2), article number em0094.

[12] Bykovska, O.V. (Ed.). (2018). Strategy for the development of extracurricular education. Kyiv: IVTS ALKON.

[13] Law of Ukraine No. 2145-VIII “On Education”. (2017, September). Retrieved from https://zakon.rada.gov.ua/laws/ show/2145-19/ed20170905\#Text.

[14] Kushnir, I.I. (2020). Modern view of educational management. Scientific Bulletin of Mukachevo State University. Series "Pedagogy and Psychology", 1(11), 28-30.

[15] Dzvinchuk, D.I., Malimon, V.I., \& Petrenko, V.P. (2007). Management of organizations. Ivano-Frankivsk: BV.

[16] Lovely, S., Buffum, A., \& Barth, R. (2007). Generations at school: Building an age-friendly learning community. Thousand Oaks: Corwin Press.

[17] Budanov, V.G. (2009). Methodology of synergetics in post-classical science and education (3 ${ }^{\text {rd }}$ ed.). Moscow: LKI Publishing House.

[18] Bekh, Yu.V. (2013). Philosophical mode of general management theory. Kyiv: National Pedagogical Dragomanov University.

[19] Gnatenko, P., \& Shevtsov, S. (2020). Social philosophy and social psychology: Dialectic of interaction. GRANI, 23(5), 87-95.

[20] Kupriy, T.H. (2014). Sociology of education. Kyiv: Logos Ukraine Publishing House. 


\title{
Ірина Юліївна Мосякова
}

Мелітопольський державний педагогічний університет імені Богдана Хмельницького 72300, вул. Гетьманська, 20, м. Мелітополь, Україна

\section{Теоретичні основи управління багатопрофільним закладом позашкільної освіти в умовах автономії}

\begin{abstract}
Анотація. Актуальним питанням у системі української та зарубіжної освіти є переосмислення методології для управління позашкільними закладами освіти. Метою статті є розкриття змісту наукових підходів і наукових дисциплін для розвитку освітнього менеджменту в багатопрофільних закладах позашкільної освіти. У дослідженні використано системний, процесуальний і синергетичний методологічні підходи до вивчення управління освітою з використанням методів аналізу та синтезу, систематизації, порівняння, аналогії. У статті наведено результати аналізу наукової літератури стосовно теоретичних підходів до управління, розкрито сутність понять, пов'язаних з освітнім менеджментом як новим напрямом у науці та практиці. Окреслено діапазон наук, що сприятимуть розбудові нової парадигми управління для багатопрофільних закладів позашкільної освіти (філософія освіти, соціальна філософія, соціальна психологія, соціологія тощо), зроблено акцент на дотриманні принципу автономізації закладу. Автором виявлено закономірності теоретичної моделі управління багатопрофільним закладом позашкільної освіти (картування індивідуальної траєкторії професійного розвитку педагогічних працівників, що сприяє глибшому розумінню їхніх потреб та, відповідно, потенційному покращенню якості надання освітніх послуг; управління взаємодією зі стейкголдерами, що сприяє отриманню інформації стосовно інтересів зацікавлених осіб, i, відповідно, коригуванню управлінських дій; управління поетапними процесами розробки і впровадження авторських освітніх програм, які мають гарантувати якість освітніх послуг, оцінювати обгрунтованість їхнього запровадження відповідно до інтересів здобувачів, аналізувати після їхньої експериментальної реалізаціі). Практична цінність роботи полягає у можливості використання матеріалів у закладах вищої освіти у межах освітніх програм «Освітні, педагогічні науки». Матеріали можуть стати у нагоді для підвищення кваліфікації керівників багатопрофільних закладів позашкільної освіти у сфері освіти дорослих (як формальна, так і неформальна освіта), у закладах післядипломної освіти для підвищення професійної компетентності адміністративних працівників багатопрофільних закладів позашкільної освіти
\end{abstract}

Ключові слова: реформування системи позашкільної освіти, системний, процесуальний і синергетичний підхід, освіта дорослих, освітній менеджмент 